\title{
Enrich Practicum to Cultivate Effective Teachers
}

\author{
Evan Ortlieb ${ }^{1, *}$ \\ ${ }^{1}$ Faculty of Education, Monash University, McMahons Road, Building A, Frankston, Victoria \\ 3199, Australia \\ *Correspondence: Tel: +61-3-9904-4661Ｅ-mail: evan.ortlieb@monash.edu
}

Received: September 10, 2012 Accepted: November 11, 2012 Published: January 13, 2013

doi:10.5296/ije.v5i1.2361

URL: http://dx.doi.org/10.5296/ije.v5i1.2361

\begin{abstract}
To advance systems of teacher education, curriculums must be enhanced with relevant activities aligned with practicum experiences to enhance the value of their education. Acting as a bridge to connect knowledge learned at the university and practical teacher applications in schools throughout the community, a research project involving several constructive activities was embedded within four literacy courses during the last two years of teacher candidates' undergraduate education. Results of this investigation demonstrate positive effects of infusing practicum experiences with systematic series of components towards becoming effective classroom teachers as well as lifelong learners and researchers.
\end{abstract}

Keywords: teacher education; practicum experiences; research; reflection 


\section{Introduction}

Curriculums for teacher candidates should focus on preparing effective teacher educators by meeting their needs, even though other agendas often guide their development. In the state of Georgia, U.S., all teacher candidates seeking certificates are required to complete 300 hours of practicum plus 600 hours of student teaching throughout four semesters. The three practica cover Practicum I (PreK-1), Practicum II (Grades $2^{\text {nd }}-3^{\text {rd }}$ ), and Practicum III (Grades $4^{\text {th }}-5^{\text {th }}$ ). Practica assignments for teacher candidates include observing their students, planning appropriate lessons, and implementing their lesson plans under the supervision of university professors, mentor teachers, and peers (Practicum Handbook, College of Education, Valdosta State University, 2009). Instead of continuing to use prescribed curriculums as is, the author designed the following case-study projects within the four literacy education courses to enrich students' practicum experience by cultivating teacher candidates' passion for teaching (Darling-Hammond, 2012). These projects are designed to expand teacher candidates' professional knowledge and skills and guide them as they develop into lifelong learners and researchers.

\section{Literacy Curriculum}

\subsection{Differentiated Instruction in Reading and Writing}

Differentiating instructional methods appropriately for all students (Chapman \& King, 2003; Walpole \& McKenna, 2007; Wong \& Wong, 2009) is a challenge within diverse communities with varying needs. Diversity encompasses physical, social, emotional, and cognitive elements (Au, 2006), and teachers must take all of these constructs into consideration when planning and implementing differentiated instructional strategies for reading and writing. During their practicum experience, teacher candidates familiarize themselves with their students' strengths and areas for improvement in reading and writing. They use the knowledge they glean to create a classroom climate conducive to learning and plan lessons that are focused on improving their students' literacy skills. Teacher candidates are also assigned one student from the practicum classroom that performs below grade level in reading and writing to work with individually to practically apply their knowledge. Teacher candidates use the website www.internet4classrooms.com/di.htm among others to determine the student's proficiencies in terms of multiple intelligences. The teacher candidate uses the information to make relevant observations and instructional decisions linked to the student's reading and writing behavior. Interviewing the student about his/her feelings towards reading and writing gives the teacher candidate insight about instructional methods to which the student is most responsive. After gathering and analyzing data related to the student's unique learning style, the teacher candidate creates individualized instructional strategies to improve the student's reading and writing (see Appendix 1).

\subsection{Graphic Novels}

Teacher candidates are encouraged to use graphic novels to help improve their students' writing skills. The exercise is designed for students who have an existing weakness in writing 
and need to make improvements. The author and teacher candidates instruct early grades students to use depictions/drawings as a prewriting exercise instead of traditional writing. By simplifying the prewriting stage of the writing process, struggling students can express their ideas through a means often viewed as less difficult than writing. As students organize their story line into a coherent panel of pictures (the graphic novel), they are creating a personal graphic organizer to use when they begin writing their stories. Children are invited to use six to eight panels of drawing (Bitz, 2004; Cornett, 2007; Gray, 2006; Short, Kauffman, \& Kahn, 2000; Siegel, 2006) to create a sequence of events that occur in their stories (Cramer, 2001). Students also use invented spellings (Gentry, 1987, 2000; Laminack \& Wood, 1996) to write one sentence below each panel of drawing to transition into standard writing. This bridge from early stages of writing to a more structured, formal approach is necessary to lessen anxiety and increase success of early writers.

\subsection{Read-Aloud and Think Aloud}

Since reading comprehension is based on a series of reasoning processes (Goodman, Watson, \& Burke, 2005; Neilsen, 1989; Thorndike, 1977), each teacher candidate is given ample practical experiences with which to begin developing elementary learners' abilities. Each teacher candidate is assigned to tutor one student. The teacher candidate begins by modeling the processes of a read-aloud (Hickman \& Pollard-Durodola, 2009) and a think-aloud (Frey, Brozo, Frey, \& Ivey, 2006; Oczkus, 2009). Once these strategies have been modeled and the elementary learner becomes familiar with the processes, the teacher candidate invites the student to participate in the read-aloud and think-aloud activities. The student participates in the think-aloud portion of the activity by explaining how he/she used various comprehension strategies throughout the read-aloud. Research-based comprehension strategies of focus include predicting, think aloud, summarization, visual representations of text, text structure, and questions/questioning (Duke \& Pearson, 2002). The teacher candidate checks the list of strategies (see Appendix 2) and analyzes the student's thinking processes in three stages: before reading, during reading, and after reading. Afterwards, additional strategies are offered to activate and guide student's thinking before reading, during reading, and after reading, maintaining pedagogical coherence and continuity (Elliot, 2012).

\subsection{Multicultural Education and Culturally Responsive Pedagogies}

In an effort to become familiarized with the learner, teacher candidates select a cultural group related to their one tutee and research the components of the culture: the people, the languages, and the learning behaviors. They use the information to design a lesson plan that addresses the unique needs of the cultural group they researched. This activity helps the teacher candidates develop their cultural awareness and improve their ability to effectively educate students from linguistically, culturally, and ethnically diverse backgrounds. This project was designed to combat xenophobia, the fear or hatred toward people who are strangers or appear to be foreigners at first glance, that was informally observed in a small number teacher candidates. 


\subsubsection{Culturally Responsive Instruction}

Teacher candidates should also be aware of the impacts social, cultural, linguistic factors have on literacy education (Au, 2006; Goldberg, 2001; Opitz, 1998) within diverse rural and urban settings. The author designed an activity that allows each teacher candidate to interview a student from an ethnic background other than his/her own. The interview is used to find out how the student's attitude towards education is influenced by his/her cultural background. A student's cultural influence will also affect his/her beliefs about education and learning styles. The interview is an effective method of gathering important data about the student while building a relationship with the student. The teacher candidate uses the information gathered in the interview to create individualized lesson plans that will improve the student's proficiency in reading, writing, listening, and speaking.

\subsubsection{Multicultural Literature}

Literature is one of the powerful tools used for combating the ignorance that breeds xenophobia. Students of all ages benefit from reading about other cultures and learning about the people of those cultures. The author designed a research-based project to minimize xenophobia, foster cultural awareness, and expose teacher candidates to the literary traditions of different world cultures and cultural groups represented in the United States. Teacher candidates were required to survey multicultural and international books written and illustrated by the native speakers (Ariza, 2006; Au, 2006; Tunnell \& Jacob, 2007) for cultural authenticity in literary groups. They had the opportunity to gain insight about the writing style of the author and gather information about the culture from the literature; it was intended to educate teacher candidates about other cultures and in turn, increase their ability to effectively teach students of diverse backgrounds.

\subsubsection{Principles for ELLs}

Although current curriculums are heavily skills-based, meaningful literacy strategies from the 1990s can be interwoven into today's classrooms. Since the beginning of the $21^{\text {st }}$ century, the population of students from culturally diverse backgrounds has steadily increased. Meanwhile, the number of certified teachers specializing in teaching English for Speakers of Other Languages (ESOL) is insufficient, and the emerging needs of these students are not being met. The author encourages teacher candidates with foreign language experience to consider obtaining ESOL or bilingual teaching certification. Teacher candidates may use approved strategies from the Whole Language Principles (Freeman \& Freeman, 2004) (see Appendix 3) to teach students from various cultural backgrounds to help develop their social and academic skills. Teaching these strategies can contribute to teacher candidates' foreign language proficiency and cultural awareness as well as promote positive academic performance from ESOL students.

\subsection{Tutoring and Literacy Assessment}

Teacher candidates are required to work with one student who struggles with reading comprehension and fluency for 20 hours throughout the semester, using an intervention program (similar in some ways to Clay's Reading Recovery, 1985) that includes diagnosis 
and improvement; further, they design individualized lesson plans built on student's interests and motivations as well. This program gives teacher candidates experience using a host of formal and informal assessment techniques to assess students' proficiencies and progress monitor improvements (Cooper \& Kiger, 2005). Teacher candidates learn to use data collected from the assessments to plan effective lessons for the tutees.

Teacher candidates are encouraged to use ideas from additional resources when designing lesson plans for their assigned student. The website www.readwritethink.org was created by the professionals from The International Reading Association (IRA) and National Council of Teachers of English (NCTE) and offers free lesson plans, state standards, and network resources.

\section{Professional Development}

\subsection{Interview and Observe the Mentor Teacher}

Mentor teachers are experienced teachers committed to modeling appropriate practice for the teacher candidates assigned to them. They aim to prepare quality teachers by enriching the teacher candidate's experience in the practicum classroom. The author requires each teacher candidate to observe and interview his/her teacher using a specific check list (see Appendix 4) based on characteristics of highly effective reading teachers outlined by Reutzel and Cooter (2008). Teacher candidates learn to use their observations along with the insight they gain from the interviews to gradually shape their educational philosophies throughout their various practicum experiences. Their educational philosophies-value, ethics, and passion for teaching, and reflections on the design of curriculum - should similarly reflect characteristics of highly effective teachers if they are to become successful classroom teachers.

\subsection{Article Review}

The author assigns each teacher candidate an article from newly released professional journals like The Reading Teacher (IRA), Language Arts (NCTE), and Journal of Adolescent \& Adult Literacy (IRA) to read and critique. Teacher candidates present their articles and critiques to the class. This assignment updates teacher candidates' knowledge in current issues and trends in literacy education. Reading relevant research-based articles expands teacher candidates' instructional knowledge base and their ability to enact these strategies into practice, and even conduct research of their own in the future (see Appendix 5).

\subsection{Professional Conference and Workshops}

The teacher candidates are offered opportunities to attend school-, county-, state-, and national conferences held by leading research organizations, such as the International Reading Association, National Council of Teachers of Mathematics, National Council of Teacher of Science, and National Council of Teachers of English. Conferences and workshops are offered throughout the year and are designed to further professional development. Teacher candidates are encouraged to join at least one research organization and stay updated on the conferences and workshops they offer. 


\section{Conclusion}

The assignments described in this article create opportunities for teacher candidates to incorporate constructive research data and innovation into their lesson plans. Teacher candidates have the opportunity to learn from one another when they present their lesson plans during class time and when they complete peer evaluations of lessons taught in the practicum classroom. Mentor teachers consistently give positive evaluations of teacher candidates and affirmative feedback for the program. These assignments give them an opportunity to update their own lessons with new techniques from the teacher candidates and make additions to their methods of planning and assessment. University professors are required to supervise teacher candidates' instruction during practicum, which gives them the opportunity to spend time in the field and gain authentic experience of "critical literacy" (Powell \& Davison, 2005).

\subsection{Recommendations}

Staying abreast of current research in teacher education is critical not only for pedagogical quality but also reflective inquiry. Moving forward is adjusting what one has done in the past with new directions and ideas; thus, careful reflection is necessary for meaningful change to occur. Teachers must continually adjust their instruction as well as their means of professional development to maintain their own interest in advances in the profession. To be teachers is to be learners first. The nexus between teaching and learning is reciprocal, and teachers must observe the learning experiences that their students offer. These principles developed in teacher education programs become instilled within teacher candidates so they begin their worthy careers prepared for today and with the knowledge and skill set for success in the future.

\section{References}

Ariza, E.N. (2006). Not for ESOL teachers: What every classroom teacher needs to know about the linguistically culturally, and ethnically diverse students. New York: Pearson Education, Inc.

$\mathrm{Au}, \mathrm{K}$. (2006). Multicultural issues and literacy achievement. Mahwah, NJ: Lawrence Erlbaum Associates, Publishers.

Bitz, M. (2004). The comic book project: Forging alternative pathway to literacy. Journal of Adolescent \& Adult Literacy, 47(7), 574-586.

Chapman, C., \& King, R. (2003). Differentiated instruction strategies for reading in the content areas. Thousand Oaks, CA: Corwin Press, Inc.

Cooper, J.D., \& Kiger, N.D. (2006). Literacy: Helping children construct meaning (6 ${ }^{\text {th }}$ ed.). Boston: Houghton Mifflin Company.

Cornett, C.E. (2007). Creating meaning through literature and the arts: An integration resource classroom teachers $\left(3^{\text {rd }}\right.$ ed.). Upper Saddle River, NJ: Pearson Merrill Prentice 
Hall.

Cramer, D. (2001). Creative power: The nature and nurture of children's writing. New York: Addison Wesley Longman, Inc.

Darling-Hammond, L. (2012). Powerful teacher education: Lessons from exemplary programs. Hoboken, NJ: John Wiley \& Sons.

Duke, N.K., \& Pearson, P.D. (2002). Effective practices for developing reading comprehension. In A.E. Farstrup \& S.J. Samuels (Eds.), What research has to say about reading instruction ( $3^{\text {rd }}$ ed., pp. 205-242). Newark, DE: International Reading Association.

Elliot, J. (2012). (Ed.). Reconstructing teacher education. New York: Routledge.

Farstrup, A.E., \& Samuels, S.J. (Eds.) (2002). What research has to say about reading instruction $\left(3^{\text {rd }}\right.$ ed.). Newark, DE: International Reading Association. http://dx.doi.org/10.1598/0872071774

Fisher, D., Brozo, W.G., Frey, N., \& Ivey, G. (2006). Content area strategies for adolescent literacy. Upper Saddle River, NJ: Pearson Merrill Prentice Hall.

Freeman, D.E, \& Freeman, Y.S. (2004). Essential linguistics: What you need to know to teach reading, ESL, spelling, phonics, grammar. Portsmouth, NH: Heinemann.

Freeman, Y.S., \& Freeman, D.E. (1992). Whole Language for second language learners. Portsmouth, NH: Heinemann.

Gentry, J.R. (1987). Spel... is a four-letter word. Portsmouth, NH: Heinemann.

Gentry, J.R. (2000). A retrospective on invented spelling and a look forward. The Reading Teacher, 54(3), 318-332.

Goldberg, M. (2001). Arts and learning: An integrated approach to teaching and learning in multicultural and multilingual settings $\left(2^{\text {nd }}\right.$ ed.). New York: Addison Wesley Longman, Inc.

Goodman, Y.M., Watson, D.J., \& Burke, C.L. (2005). Reading miscue inventory: From evaluation to instruction ( $2^{\text {nd }}$ ed.). New York: Richard C. Owen Publishers, Inc.

Gray, E.C. (2006). Children's use of language and pictures in classroom inquiry. Language Arts, 83(3), 227-237.

Hickman, P., \& Pollard-Durodola, S.D. (2009). Dynamic read-aloud strategies for English learners: Building language and literacy in the primary grades. Newark, DE: International Reading Association.

Laminack, L.L., \& Wood, K. (1996). Spelling in use. Urbana, IL: National Council of Teachers of English.

Lu, L.Y. (2008). Semiotics for integrating geosciences into literacy in teacher education. In 
V.L. Akerson (Ed.), Interdisciplinary language arts and science instruction in elementary classrooms: Applying research to practice (pp.263-277). Mahwah, NJ: Lawrence Erlbaum Association.

Neilsen, A.R. (1989). Critical thinking and reading: Empowering learners to think and act. Urban, IL: National Council of Teachers of English.

Norton, D.E., \& Norton, S.E. (2006). Through the eyes of a child: An introduction to children's literature ( $7^{\text {th }}$ ed.). Upper Saddle River, NJ: Pearson Merrill Prentice Hall.

Oczkus, L. (2009). Interactive think-aloud lessons: 25 surefire ways to engage students and improve comprehension. New York: Scholastic.

Opitz, M.F. (Ed.) (1998). Literacy instruction for culturally and linguistically diverse students. Newark, DE: International Reading Association.

Piazza, C.L. (1999). Multiple forms of literacy: Teaching literacy and the arts. Upper Saddle River, NJ: Merrill.

Practicum Handbook. (2009). College of Education, Valdosta State University. Valdosta, GA.

Reutzel, S.R., \& Cooter, R.B. (2008). Teaching children to read: Teacher makes the difference $\left(5^{\text {th }}\right.$ ed.). Upper Saddle River, NJ: Pearson Merrill Prentice Hall.

Short, K.G., Kauffman, G., \& Kahn, L.H. (2000). I need to draw: Responding to literature across multiple sign systems. The Reading Teacher, 54(2), 160-171.

Siegel, M. (2006). Rereading the signs: Multimodal transformations in the field of literacy education. Language Arts, 84(1), 65-77.

Tunnell, M.O., \& Jacob, J.S. (2007). Children's literature briefly (4 ${ }^{\text {th }}$ ed.). Upper Saddle River, NJ: Pearson Merrill Prentice Hall.

Walpole, S., \& McKenna, M.C. (2007). Differentiated reading instruction: Strategies for the primary grades. New York: The Guilford Press.

Wong, H.K., \& Wong, R.T. (2009). The first day of school: How to be an effective teacher. Mountain View, CA: Harry K. Wong Publications, Inc. 
Appendixes

Appendix 1. Directions for Differentiated Instruction Project

\section{SUBJECT}

You have to work with one struggling learner (Grades 1-5) to complete this assignment.

If you are a Classroom Teacher, you will pick up one struggling learner in your class,

Or you will request your mentor teacher to refer you a struggling learner if you are a Teacher Aqn+kdgroUCTION (1 point)

You will introduce the child (to protect the child's privacy, use Adam for a boy, and Eve for a girl) about his/her age, interest, favorite books, favorite movies, favorite food, favorite sports, life goals, family background, etc. Please survey www.internet4classrooms.com/di-htm to find out the leaner's strength in terms of multiple intelligences.

\section{PROCEDURES}

(You may use the handout as a guideline for your observation, the child's feeling \& your prescription)

\section{Reading (4 points)}

Observation (1 point): You will invite the child to read a book which is 1 or 2 levels above his/her current reading level. You will write your observation describing his/her reading behavior.

Interview (1 point): You will invite the child to share with you his/her feeling about reading.

Your Prescription (2 points): You will offer your prescription to help the child improve his/her reading

\section{$\underline{\text { Writing (5 points) }}$}

Observation (2 points): You will Invite the child to write for 10 minutes with the topic like a family story, feeling, or anything he/she is interested in (you have to include his/her writing sample - type it).You will write your observation describing his/her writing behavior.

Interview (1 point): You will invite the child to share with you his/her feeling about writing.

Your Description (2 points): You will offer your prescription to help the child improve his/her writing.

\section{Graphic Novel (5 points)}

You may invite the same child to tell you a family story or his/her feeling by drawing 6-8 panels of graphic novel (comic strips) and writing one sentence below each panel.

*The observation, learner's feeling and your prescription should be aligned with one another.

Format for Differentiated Strategies for Reading in the Content Areas (Chapman \& King, 2003) 


\section{Emerging Emily}

\begin{tabular}{|c|c|c|}
\hline $\begin{array}{l}\text { Reading Behaviors } \\
\text { (observation) }\end{array}$ & Feelings of the Reader & Suggested Prescription \\
\hline \multirow{11}{*}{$\begin{array}{c}\text { Reads very little } \\
\text { Reads a few words on grade } \\
\text { level } \\
\text { Exhibits poor comprehension } \\
\text { skills } \\
\text { Does not like to read } \\
\text { Struggles with word attach } \\
\text { skills } \\
\text { His limited language ability }\end{array}$} & I feel lost when I read & Unmotivated \\
\hline & I will never learn to read, & Pass on the joy and love of reading \\
\hline & so I will be in this grade & through modeling it \\
\hline & the rest of my life & Provide a variety of high-interest, \\
\hline & I cannot read this & love-level materials \\
\hline & assignment & Create a print-rich environment \\
\hline & I am embarrassed to read, & $\underline{\text { Has a Limited Reading Vocabulary }}$ \\
\hline & so please do not call on me & Use Language Experience activities \\
\hline & This is boring and & $\underline{\text { Needs Word Attack Skills }}$ \\
\hline & frustrating & Teach decoding skills \\
\hline & $\begin{array}{c}\text { I will misbehave, so I will } \\
\text { not read }\end{array}$ & Use word families to teach patterns \\
\hline & & \\
\hline
\end{tabular}

\section{Word-Calling Wayne}

\begin{tabular}{|c|c|c|}
\hline Reading Behavior (observation) & Feelings of the Reader & Suggested Prescription \\
\hline $\begin{array}{l}\text { Read one of two words at a time } \\
\text { Lacks oral reading fluency \& } \\
\text { comprehension } \\
\text { Does not enjoy reading }\end{array}$ & $\begin{array}{l}\text { I hope no one asks me to read } \\
\text { aloud } \\
\text { I know I cannot read as well as } \\
\text { my friends }\end{array}$ & $\begin{array}{l}\text { Model reading using short, easy, } \\
\text { familiar passages. } \\
\text { Train eyes for left-to-right } \\
\text { movement }\end{array}$ \\
\hline $\begin{array}{l}\text { Reacts negatively when asked to } \\
\text { read aloud }\end{array}$ & $\begin{array}{l}\text { I understand more when } \\
\text { someone reads to me } \\
\text { I read it, but I don not know } \\
\text { what it says } \\
\text { I read it, but I do not know the } \\
\text { answers } \\
\text { I am so embarrassed }\end{array}$ & $\begin{array}{c}\text { Build word recognition speed } \\
\text { using repetition of familiar words, } \\
\text { phrased and sentences } \\
\text { Embed word families in unit } \\
\text { lessons } \\
\text { Provide easy reading materials } \\
\text { Practice reading repetitive phrased } \\
\& \text { rhymes } \\
\text { Teach words used every day. }\end{array}$ \\
\hline
\end{tabular}


Silent Reading Sam

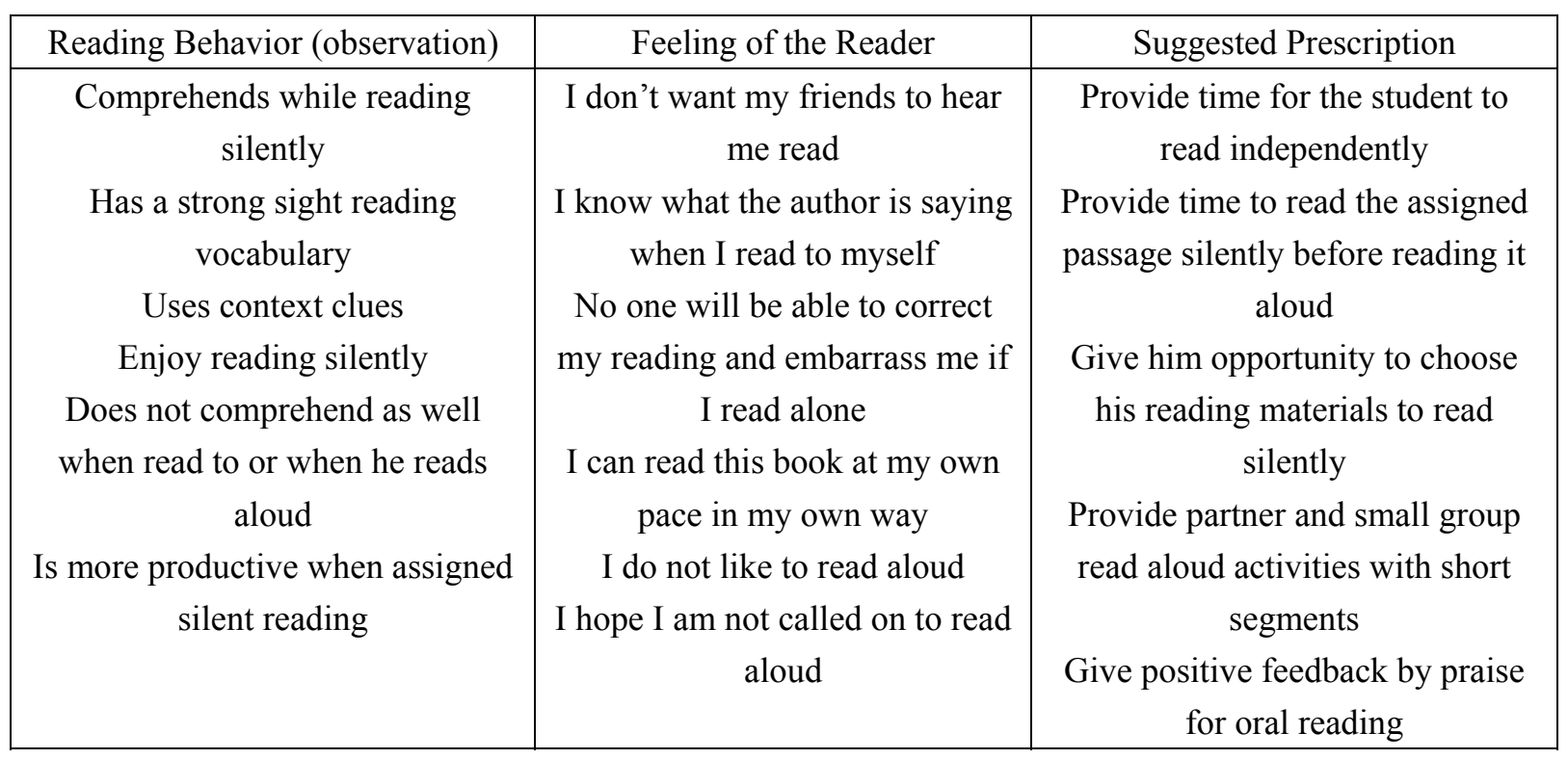

\section{Appendix 2. Read-Aloud and Think Aloud}

Reading is Reasoning (Thorndike, 1977)

Reading is reasoning or thinking when readers actively exercise their INFERENCE - the thinking processes - anomaly, abduction, deduction and induction - to make meaning of the text.

Speak out comprehension processes: making predictions, creating images, linking information in text with prior knowledge or life experiences

Assessment: self-monitoring comprehension, and using various fix-up strategies to solve problems by phonics (decoding), illustration, word recognition, vocabulary, syntax clues toward comprehension.

\section{Before Reading}

_ Surveyed title, headings, illustrations

_ Thought about what s/he knows about the topic against his/her life experience

Predicted what the text might be about

_ Made up a question to answer

_ Visualized

_ Other (describe it)

During Reading

_ Predicted what might happen next

_ Inferred ideas not stated

_ Got main idea of section

_ Got important details

_ Summarized each section

_ Created images about parts of the 
selections

_ Thought about what s/he had read

Judged whether information was true or the story seemed real

Made up questions to be answered

_ Checked to make sure $\mathrm{s} / \mathrm{he}$ was understanding what $\mathrm{s} / \mathrm{he}$ read

_ Repaired by rereading puzzling parts, getting meaning of hard words, etc.

Others (Describe it)

Post-Reading

_ Summarized what (s)he had read

— Thought about what (s)he had read

_ Connected what (s)he had read to what (s)he already knew

_ Applied what (s)he had learned in the selection

Other (describe it)

Post-Reading Discussion

"What pictures did you create in your mind as you read?"

"Were there any confusing passages?"

"How did you handle them?"

Post-reading discussing strategies help students respond to clarify their use of strategies \& learn how others process text.

Appendix 3. Language Principles by Freeman and Freeman (1994)

1. Learning proceeds from whole to part.

2. Lessons should be learner centered because learning is the active construction of knowledge by the student.

3. Lessons should have meaning purpose for students now.

4. Learning takes place as groups engage in meaningful social interaction.

5. In a second language, oral and written language are acquired simultaneously.

6. Learning should take place in the first language to build concepts and facilitate the acquisition of English

7. Learning potential is expanded through faith in the learners. 
Appendix 4. Interview and Observe a Successful Reading Teacher

Check List:

1. The teacher understands the structure of language

- This teacher activated students' prior knowledge about the topic

_ This teacher used creative ways to build up vocabulary \& concept knowledge of the new topic

2. The teacher assesses learners' needs to plan appropriate instruction

_ The teacher assesses students' understanding of the topic

_ The teacher activated students' prior knowledge of the topic

_ The teacher assessed students' learning progress and final products

3. The teacher constructs well-organized and print-rich environment

Word Walls

_ Message Center

_ Students' Artifacts

_ Children Literature with different genres

_ Real World Objects — magazines and news papers

_ Subjects Learning Centers

4. The teacher supports reading to, with and by students

The teacher supports reading by...

_ Reading to the students everyday minutes

_ Reading with students everyday minutes

_ Inviting students to do the following activities...

_ Silent reading individually

_ Small group reading/ discussion

_ Role play

_ Readers Theatre

_ Whole class reading/ discussion

5. The teacher uses research-based instruction

The teacher attended the reading/ writing workshops

The teacher attended the national or state reading conferences

_ The teacher has the newly released professional journals like The Reading

Teacher, Language Arts, Instructors on his/her desk 
6. The teacher explicitly models the strategies

_ The teacher demonstrated how to use the strategies in his/her instruction

_ The teacher invited students to follow his/her model and correct their reading behaviors

7. The teacher integrates across the curriculum

_ The teacher integrates, reading, writing, listening, speaking and critical thinking in his/her instruction

- The teacher integrates arts, dance, math, music, science, literature and social studies in his/her reading curriculum

8. The teacher implements differentiate instruction for learners with special needs

_ Cognitive need

_ Physical need

_ Social need

_ Cultural need

_ Economic need

_ Language need

_ Emotional need

_ Religious need

9. The teacher involves family and community

_ The teacher involved family, church, local library, and community in his/her reading program

10. The Teacher is an excellent classroom manager Allocates classroom space for multiple uses

_ Supplies and arrange classroom materials

_ Clearly communicates expectation and rules with a positive classroom climate Employs effective instructional practices

_ Effectively trains students in classroom routines and procedures

_ Establishes a predictable and familiar classroom schedule 
Appendix 5. Article Review

Objective

As a researcher and a research-based classroom teacher, you will know:

How to implement research-based strategies into the classroom

How to put theory into practice

How to conduct research

How to be critical

How to be innovative

How to be collaborative with your colleagues

$\underline{\text { Format }}$

Cover Page: title, author, resource, and presenters

Statement of problem

Objective of this research

Literature Review (6 citations)

Methods: subjects, methods of data collection, data analysis and findings

Your critique

Your plan to implement this strategy into your instruction

Interact with the audience by questions \& answers

\section{Copyright Disclaimer}

Copyright reserved by the author.

This article is an open-access article distributed under the terms and conditions of the Creative Commons Attribution license (http://creativecommons.org/licenses/by/3.0/). 